\title{
Synonymy of the potter wasp genus Philippodynerus Gusenleitner (Hymenoptera, Vespidae, Eumeninae) with Apodynerus Giordani Soika, with taxonomic notes on Apodynerus species
}

\author{
Hari Nugroho', Jun-ichi Kojima², Rosichon Ubaidillah' \\ I Museum Zoologicum Bogoriense, Research Center for Biology, Indonesian Institute of Sciences, Jl. Raya Ja- \\ karta-Bogor Km 46, Cibinong, Bogor, Indonesia 2 Natural History Laboratory, Faculty of Science, Ibaraki \\ University, Mito, 310-8512 Japan \\ Corresponding author: Hari Nugroho (hntawon@gmail.com)
}

Academic editor: W. Pulawski | Received 17 December 2013 | Accepted 1 February 2014 | Published 14 February 2014

Citation: Nugroho H, Kojima J-i, Ubaidillah R (2014) Synonymy of the potter wasp genus Philippodynerus Gusenleitner (Hymenoptera, Vespidae, Eumeninae) with Apodynerus Giordani Soika, with taxonomic notes on Apodynerus species. Journal of Hymenoptera Research 36: 131-151. doi: 10.3897/JHR.36.6830

\begin{abstract}
Philippodynerus omicroniformis Gusenleitner, 1996, the type species of the monotypic potter wasp genus Philippodynerus Gusenleitner, 1996, is a synonym of Apodynerus gregarioides (Giordani Soika, 1986), and consequently Philippodynerus Gusenleitner, 1996 is synonymized under Apodynerus Giordani Soika, 1993. Taxonomic notes on Apodynerus species are given, including two new synonymies for Apodynerus troglodytes troglodytes (de Saussure, 1856): A. t. karimonensis (van der Vecht, 1937), syn. n. and A. t. baliensis (Giordani Soika, 1987), syn. n. A synoptic key to species and a revised species checklist are provided.
\end{abstract}

\section{Keywords}

Potter wasps, Vespidae, Eumeninae, Apodynerus, Philippodynerus, new synonymy 


\section{Introduction}

The potter wasp genus Apodynerus was proposed for Odynerus troglodytes de Saussure, 1856 (Giordani Soika 1993a). Giordani Soika (1994) redescribed Apodynerus treating it as a new genus, and included in it six species that had been until then placed in Pachymenes de Saussure, 1852 and also one newly described species. The genus Philippodynerus was proposed by Gusenleitner (1996) together with a description of the only included species, Philippodynerus omicroniformis.

We examined the holotypes of Philippodynerus omicroniformis Gusenleitner, 1996 and Apodynerus gregarioides (Giordani Soika, 1986) [= Pachymenes gregarioides Giordani Soika, 1986], and came to the conclusion that they are synonymous. Consequently Philippodynerus Gusenleitner, 1996 is synonymized under Apodynerus Giordani Soika, 1993. The present paper also provides taxonomic notes on some other species of Apodynerus including new synonymies, a synoptic key to all the species of Apodynerus, and a revised species checklist.

\section{Materials and methods}

The materials examined are deposited in the Natural History Collection at Ibaraki University, Mito, Japan (IUNH), Systematic Entomology Institute, Hokkaido University Museum, Sapporo, Japan (SEIHU), Museum Zoologicum Bogoriense, Cibinong, Indonesia (MZB), and Forestry and Forest Products Research Institute, Tsukuba, Japan (FFPRI).

The acronyms for other type repositories are as follows: BMNH - The Natural History Museum, London; ETHZ - Entomologisches Institut, Technische Hochschule, Zürich; LACM - Natural History Museum of Los Angeles County, Los Angeles, California; MRSN - Museo Regionale di Scienze Naturali, Torino; MVEN - Museo Civico di Storia Naturale, Venice; OLM - Oberösterreichischen Landesmuseum, Linz; OUM - Hope Entomological Collection, Oxford University Museum, Oxford, UK; RMNH - Nationaal Natuurhistorisch Museum (formerly Rijksmuseum van Natuurlijke Historie), Leiden.

Morphological characters and color patterns were examined on pinned-and-dried specimens under a stereoscopic dissecting microscope. Drawings were made using the drawing tube attached to the microscope. Terminology mainly follows Carpenter and Cumming (1985) and Yamane (1990).

\section{Synonymy of Philippodynerus under Apodynerus}

The holotypes of Philippodynerus omicroniformis Gusenleitner and Apodynerus gregarioides (Giordani Soika) are both males and collected in the same locality, Palo on Leyte 
Island, the Philippines. We examined these holotypes and they are only slightly different from each other, allowing us to conclude that they are the same species, and thus we synonymize Philippodynerus omicroniformis under Apodynerus gregarioides. The holotype of P. omicroniformis differs from that of Apodynerus gregarioides (character states for the latter are given in square brackets) as follows: clypeus proportionally slightly wider, 1.17 [1.13] $\times$ as wide as high in frontal view; metasomal tergum I slightly stouter (Fig. 7), 1.4 [1.45 (Fig. 6)] $\times$ as long as its apical width; mesoscutum posteriorly with paired small ferruginous spots [absent]; metasomal sternum II with no basal markings (Fig. 5) [with paired lateral yellow spots basally (Fig. 4)].

We did not find any characters that would allow us to differenciate $A$. gregarioides [=Philippodynerus omicroniformis, the type species of Philippodynerus] from the other species of Apodynerus at the generic level. Consequently Philippodynerus Gusenleitner, 1996 is synonymized under Apodynerus Giordani Soika, 1993.

\section{Taxonomy}

\section{Apodynerus Giordani Soika, 1993}

http://species-id.net/wiki/Apodynerus

Apodynerus Giordani Soika, 1993a: 155, genus; reference to Apodynerus Gusenleitner, 1988. Type species: Odynerus troglodytes de Saussure, 1856, by original designation and monotypy.

Apodynerus Gusenleitner, 1988: 180, used as generic name in the combination "Apodynerus (VDV.i.sch.) t. troglodytes (SAUSSURE 1856)”. Unavailable under Article 13.1.1 of the Code (ICZN 1999).

Apodynerus Giordani Soika, 1993b: 22. Nomen nudum.

Apodynerus Giordani Soika, 1993c: 27. Nomen nudum.

Philippodynerus Gusenleitner, 1996: 39, genus. Type species: Philippodynerus omicroniformis Gusenleitner, 1996, by original designation and monotypy. Syn. n.

Note. The characters given in the key for $A$. amandus Gusenleitner, 2002, A. diffinis Giordani Soika, 1996, A. rufipes Giordani Soika, 1994 and A. nitidiclypeus Gusenleitner, 2013, were taken from the original descriptions (Giordani Soika 1994, 1996, Gusenleitner 2002, 2013), and for $A$. formosensis (von Schulthesses, 1934), from Giordani Soika (1994). The characters in the key are applicable to both sexes unless the sex is mentioned.

\section{Key to species of Apodynerus}

1 Anterior face of pronotum densely punctured, with median pit. Female clypeus truncated apically; in frontal view nearly entirely flattened, with distinctly carinate border; in lateral view flattened 
- $\quad$ Anterior face of pronotum glossy and slightly punctured laterally, without median pit and with series of median striae. Female clypeus in frontal view more or less convex, without carina; in lateral view more or less convex...... 2

2 Female clypeus truncated apically. Punctures on frons moderately dense in lower half, sparser and superficial in upper half; posterior part of vertex and gena with large, sparse punctures. Propodeum with lateral face distinctly separated from dorsal face. A. rufipes Giordani Soika

- $\quad$ Female clypeus at least slightly emarginate apically (Figs 2, 11-14, 41). Punctures on frons and vertex more or less dense, slightly smaller and sparser in posterior part of vertex. Border between lateral face and dorsal face of propodeum ill-defined

Submarginal carina of propodeum long, narrow, curved upwards and sharply pointed. Mesepisternum smooth and glossy, with superficial punctures. Metanotum obtusely dentiform. Male terminal flagellomere slender, curved backwards, apically nearly reaching the base of flagellomere IX

\section{A. flavospinosus (Giordani Soika)}

Submarginal carina of propodeum short and wide. Mesepisternum usually with dense punctures. Metanotum dentiform or not. Shape of male terminal flagellomere variable

Tergum II in lateral view only slightly convex dorsally (Fig. 24); basomedian furrow of metasomal sternum II distinct.

Tergum II in lateral view convex dorsally (Figs 4, 25-27); basomedian furrow of metasomal sternum II absent or inconspicuous.... Clypeus with sparse and superficial punctures. Mesepisternum with dense punctures; interspaces between punctures cariniform. Body entirely covered with long and dense setae.....

A. icarioides (Bingham)

Clypeus with dense and deep punctures. Mesepisternum with dense punctures; interspaces non-cariniform. Body with short setae.

\section{A. formosensis (von Schulthess)}

Metanotum sharply dentiform. Metasomal segment I proportionally long, $0.6 \times$ as long as mesosoma (Figs 4, 5); in dorsal view more or less smoothly widened posteriorly (Figs 6,7). Male terminal flagellomere flattened dorsoventrally, long and curved backwards, apically reaching the base of flagellomere IX (Figs 8, 9) A. gregarioides (Giordani Soika) Metanotum obtuse or non-dentiform. Metasomal segment I proportionally short, about or less than $0.4 \times$ as long as mesosoma; in dorsal view abruptly widened at the base (Fig. 30). Male terminal flagellomere short in most specimens (Figs 28, 29)

Female clypeus about as wide as high. Metanotum non-dentiform. Metasomal sternum II without basomedian furrow A. amandus Gusenleitner

- $\quad$ Female clypeus wider than high (Figs 11, 12, 41-47). Metanotum hardly to obtusely dentiform. Metasomal sternum II with inconspicuous basomedian furrow. 
8 Metasomal tergum II with dense punctures in anterior half, interspace between punctures smaller than puncture, punctures becoming smaller but denser towards apex. Tergum I in lateral view abruptly swollen dorsally

A. diffinis Giordani Soika

- $\quad$ Metasomal tergum II more or less uniformly punctured. Tergum I in lateral view gradually swollen dorsally (Figs 25-27).....................................9

9 Ventral margin of clypeus proportionally wider, about $0.3 \times$ maximum width of clypeus (Figs 41-47). Metasomal tergum II in lateral view more or less evenly and slightly convex dorsally (Fig. 25) ....A. troglodytes (de Saussure)

- Ventral margin of clypeus proportionally narrower, about $0.2 \times$ the maximum width of clypeus (Figs $11,12,15,16)$.................................... 10

10 Female clypeus about $1.2 \times$ as wide as high (Fig. 11). Gena wider ventrally (Fig. 21). Anterior face of pronotum with distinct striae. Mesosoma proportionally long and slender, $1.4 \times$ as long as high ....... A. yayeyamensis (Matsumura)

- $\quad$ Female clypeus about $1.1 \times$ as wide as high (Fig. 12). Gena wider dorsally (Fig. 22). Anterior face of pronotum without distinct striae. Mesosoma proportionally short and stout, $1.2 \times$ as long as high

A. quadricolor Giordani Soika, stat. n.

\section{Apodynerus gregarioides (Giordani Soika)}

http://species-id.net/wiki/Apodynerus_gregarioides

Figs 1, 2, 4, 6, 8, 10

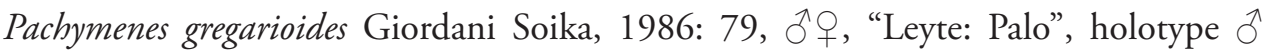
(IUNH).

Philippodynerus omicroniformis Gusenleitner, 1996: 39, 40, §ิ, "Philippines, Palo, Leyte, Naga-Naga”, holotype (SEIHU). Syn. n.

Diagnosis. MALE: Head in frontal view about as wide as high; clypeus as wide as high (Figs 1, 3), in lateral view with anterior margin slightly convex dorsally and nearly straight ventrally (Fig. 10); labrum broadly rounded apically; apicalmost tooth of mandible long and sharp; gena narrow (Fig. 10); antennal flagellomeres IX and X flattened ventrally, flagellomere $\mathrm{X}$ smaller than preceding flagellomeres; mesosoma slender, 1.4 $\times$ as long as high and $1.3 \times$ as long as wide; pronotum with distinct and well-developed striae on vertical anterior face; propodeum with shallow and narrow (less than half as wide as width of propodeum) concavity on posterior face; propodeal valvula subrectangular, not fused to submarginal carina; propodeal orifice oval; second submarginal cell of fore wing petiolate basally; metasomal segment I proportionally longer than that of any other species, $0.6 \times$ as long as mesosoma; sternum VII with longitudinal carina at least in anterior half, latero-basally with brush-like setae. FEMALE: Head in frontal view about as wide as high; clypeus proportionally wider than that of male, $1.2 \times$ as wide as high (Fig. 2); mesosoma $1.5 \times$ as long as wide. 

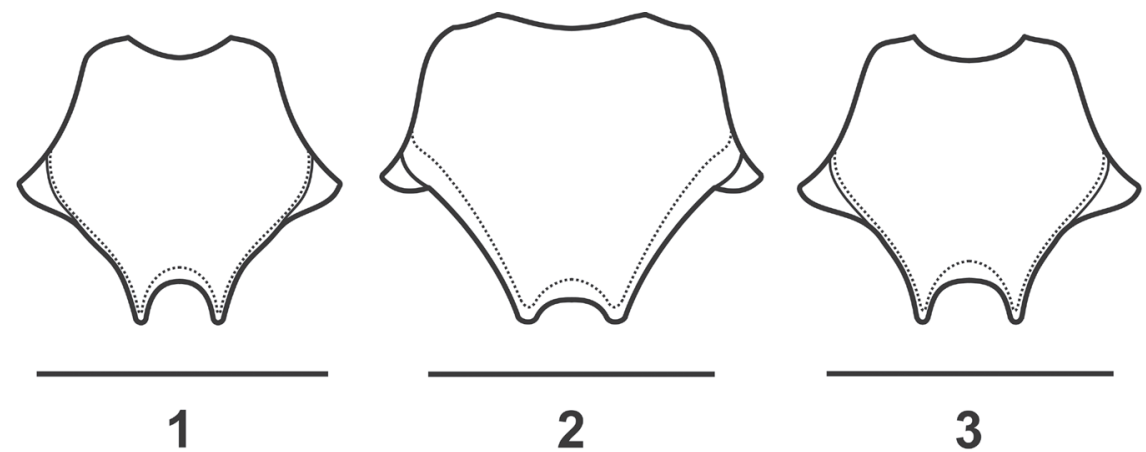

3
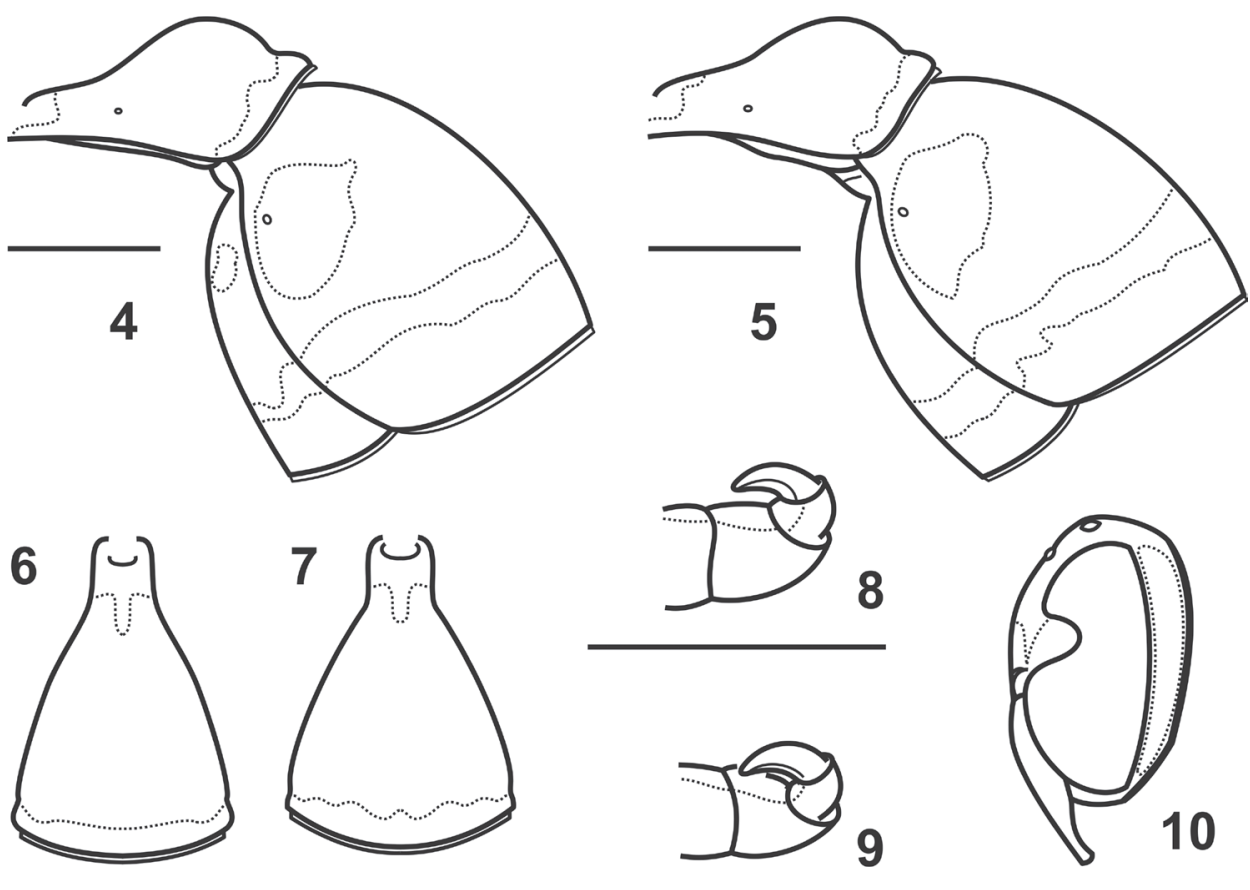

Figures I-10. Apodynerus gregarioides. I, 4, 6, 8, $\mathbf{1 0}$ holotype $ð \mathbf{2}$ paratype - allotype $q$. Philippodynerus omicroniformis 3, 5, 7, 9 holotype $\delta$ I-3 clypeus 4, 5 Metasomal segments I-II, lateral view 6, 7 Metasomal tergum I, dorsal view 8, 9 Apical part of antenna 10 Head, lateral view. Scale $1 \mathrm{~mm}$.

Material examined. PHILIPPINES: LEYTE I.: 1 o (IUNH; holotype of Pachymenes gregarioides), labeled "Palo, Leyte, Philippines, 1978.3.20, J. Kojima" and "Holotypus Apodynerus gregarioides Giordani Soika"; $10 \hat{~}$ (SEIHU; holotype of Philippodynerus omicroniformis), labeled "Naga-Naga, Palo, Leyte, Philippines, 1978.3.25, J. Kojima" and "Philippodynerus omicroniformis nov. Spec. O', J. Gusenleitner, det. 1996, Holotypus"; LUZON I.: 1 9 , C.L.S.U. [Central Luzon State University], Munoz, Nueva Ecija, 18 Apr.1980, J. Kojima (IUNH; paratype of Pachymenes gregarioides). 
Remarks. This species is only known from the areas given in the original description (Luzon and Leyte, the Philippines). Giordani Soika (1994) recorded this species from Lokojengo on Sumba Island, Lesser Sunda Islands. The occurrence of this species on Sumba, however, needs confirmation, considering the unusual disjunct distribution and possibility of misidentification with the other species known from the Lesser Sunda Islands, such as A. rufipes Giordani Soika and A. quadricolor Giordani Soika.

\section{Apodynerus flavospinosus (Giordani Soika)}

http://species-id.net/wiki/Apodynerus_flavospinosus

Figs 13, 17, 20, 23

Pachymenes flavospinosus Giordani Soika, 1986: 80, 으, "Naga Naga, Leyte, Palo", holotype + (IUNH).

Diagnosis. The species can be easily distinguished from other Apodynerus by the peculiar shape of the submarginal carina, which is long, narrow, sharply pointed and curved upwards. The following combination of characters also helps distinguish this species from its congeners: female clypeus in frontal view wider than high, $1.2 \times$ as wide as high (Fig. 13); male clypeus in frontal view proportionally narrower than in female, as wide as high (Fig. 17); metanotum obtusely dentiform; metasomal tergum I in lateral view moderately convex dorsally, then slightly concave preapically (Fig. 23).

Material examined. PHILIPPINES: LEYTE I.: 1 (IUNH; holotype of Pachymenes flavospinosus), labeled "Naga-Naga, Palo, Leyte, Philippines, 1978.3.26, J. Kojima" and "Holotypus Apodynerus flavispinosus"; 1 †, 1 ภ (IUNH; paratypes of Pachymenes flavospinosus), Naga-naga, Palo, 25 Mar.1978, J. Kojima; 11 ㅇ, 11 ठ (IUNH; paratypes

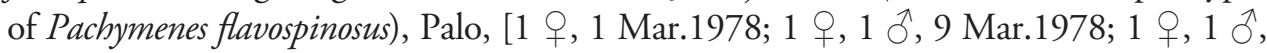

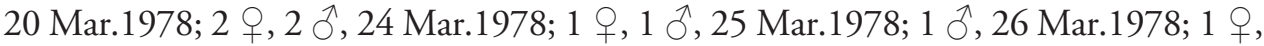

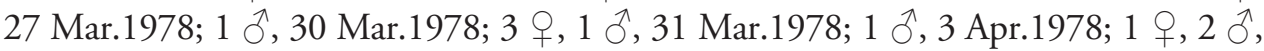
20 Jun.1980], J. Kojima; 1 ㅇ (IUNH; paratype of Pachymenes flavospinosus), Burauen, 5.

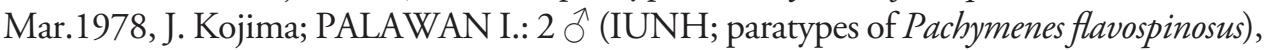
St. Pedro, Puerto Princesa, 29. Apr.1980, J. Kojima; 4 + 7 7 (IUNH; paratypes of $\mathrm{Pa}$ chymenes flavospinosus), Puerto Princesa, [1 क , 2 đ , 23 Apr.1980; 1 ô, 26 Apr.1980; 3 +

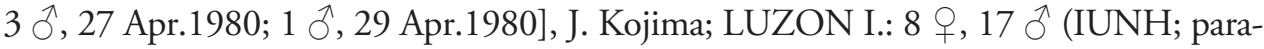
types of Pachymenes flavospinosus), Univ. Phil. Los Banos, Laguna, [1 9,18 Mar.1980;

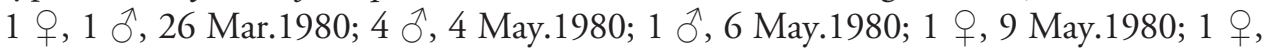

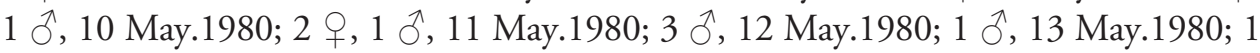

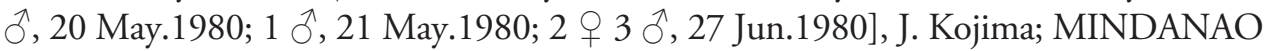
I.: 1 § (IUNH; paratype of Pachymenes flavospinosus), C.M.U. Musuan, Bukidnon, 28. May.1980, J. Kojima; 1 đิ (SEIHU), Zamboanga, 13 Jun.1933, K. Kuwasima.

Remarks. This species is only known from the Philippines. 


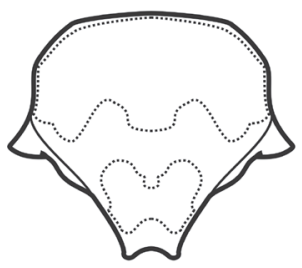

11

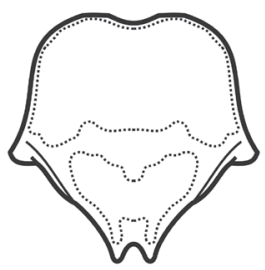

15

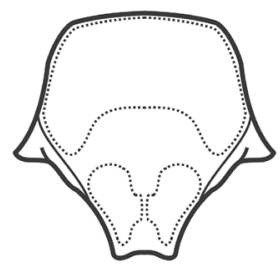

12

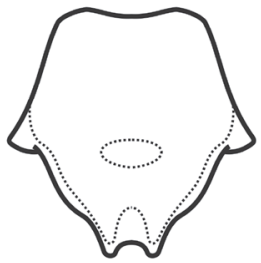

16

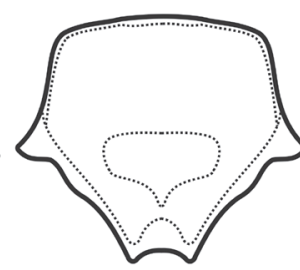

13

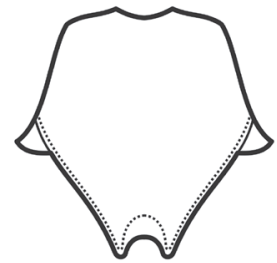

17

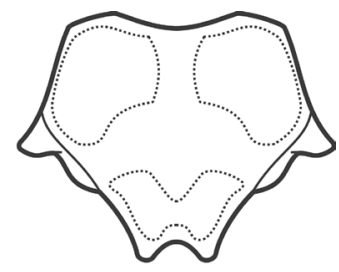

14

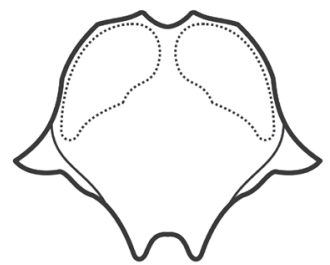

18

Figures II-I8. Apodynerus species. II-I4 $\odot$ I5-18 9 . I I, I5 A. yayeyamensis I 2, I6 A. quadricolor 13, I7 A. Alavospinosus, holotype and paratype - allotype, respectively I4, I8 A. icarioides I I-I8 Clypeus, frontal view.

\section{Apodynerus icarioides (Bingham)}

http://species-id.net/wiki/Apodynerus_icarioides

Figs 14, 18, 19, 24, 29

Odynerus icarioides Bingham, 1897: 363 (in key to aculeates of British India), 372, ㅇ, "Tenasserim", type (BMNH).

Diagnosis. This species can be distinguished from other species of Apodynerus by the combination of the following characters: head in frontal view subcircular, slightly wider than high, $1.1 \times$ as wide as high; female clypeus in frontal view wider than high, $1.3 \times$ as wide as high, with dorsal and ventral margins distinctly emarginate medially (Fig. 14); male clypeus in frontal view proportionally narrower than that of female, $1.15 \times$ as wide as high (Fig. 18); gena wide (Fig. 19); metanotum obtusely dentiform; metasomal tergum I stout, in lateral view swollen dorsally from base to mid-length, then moderately concave preapically (Fig. 24); metasomal tergum II in lateral view slightly convex dorsally (Fig. 24).

Material examined. INDONESIA: Kalimantan: 2 , Bukit Soeharto, East Kalimantan, 3, 23 Feb.1998, H. Makihara (FFPRI); 1 ㅇ, Mentawir River, about 50 m, Balikpapan, East Kalimantan, Oct.1950, A.M.R. Wegner (MZB); 1 đ, Kayan Mentarang Nature Reserve, Pujungan, East Kalimantan, Apr.1993, D.C. Darling \& R. Ubaidillah (MZB).

Remarks. This species shows a disjunct distribution pattern, occurring in India and Myanmar, and on Borneo. Van der Vecht (1937) examined the type and provided a diagnosis for this species. 


\section{Apodynerus yayeyamensis (Matsumura)}

http://species-id.net/wiki/Apodynerus_yayeyamensis

Figs 11, 15, 21, 26

Odynerus yayeyamensis Matsumura, 1926, in Matsumura and Uchida 1926: 36, गे, "Okinawa (Okinawa-honto)" [possibly erroneously listed locality], lectotype from Yaeyama Islands (SEIHU).

Odynerus hokotoensis Sonan 1929: 534, 우, [Taiwan:] "Hôkotô ... Takao". Holotype + originally in "Entomological Laboratory, Taihoku Imperial University", but current depository unknown.

Description of female and lectotype male. FEMALE. Head in frontal view about as wide as high. Clypeus in frontal view wider than high, $1.2 \times$ as wide as high (Fig. 11). Vertical anterior face of pronotum with series of conspicuously produced striae. Metanotum compressed, obtusely dentiform; posterior margin oblique in lateral view. Metasomal tergum II in lateral view distinctly swollen anterodorsally and barely convex in posterior two-thirds (Fig. 26).

Head and mesosoma black, with following yellow markings: interantennal spot, ocular sinus, scape ventrally, mandible basally, band on gena, large dorsal spot and ventral scrobal spot on clypeus; anterior half of dorsal face of pronotum interrupted medially; spot on upper part of mesepisternum, tegula except median ferruginous spot, parategula, scutellum nearly entirely, large spots on dorsal face of propodeum; antenna dark brown. Legs black, but apical part of fore and mid femora and outer face of tibiae yellow. Metasoma black, with following yellow markings: tergum I: paired sublateral bands running obliquely towards posterolateral corner of tergum and apical band; segment II: basal lateral spots on tergum, and apical band.

Lectotype male. Clypeus in frontal view about as wide as high; ventral margin proportionally narrow (Fig. 15), about $0.2 \times$ the maximum width of clypeus. Scape $3.3 \times$ as long as its maximum width; flagellomere $\mathrm{X}$ small; flagellomere XI minute, curved backward, with apex reaching about half length of flagellomere IX. Mandible with five teeth; apicalmost tooth long and sharp.

Mesosoma in lateral view about $1.4 \times$ as long as high; in dorsal view about $1.3 \times$ as long as wide. Metanotum dorsally with closely pair of obtuse teeth. Propodeum with somewhat deep median concavity on posterior face, in lateral view strongly convex.

Lateral face of propodeum with dense, strong punctures, in most specimens forming ridges between punctures. Metasomal segment I with dense, conspicuous deep punctures; segments II-VII with dense, deep punctures.

Black, with following yellow markings: interantennal spot, spot filling ocular sinus extending ventrally to antennal socket, band on gena, clypeus except apical ferruginous band and black transverse band at level of lateral lobes, scape except black dorsal face, mandible except ferruginous tip and narrow black band along outer margin; anterodorsal part of pronotum, scrobal spot on mesepisternum, tegula except ferruginous mid spot and outer margin, parategula, scutellum nearly entirely, spot on metanotal 


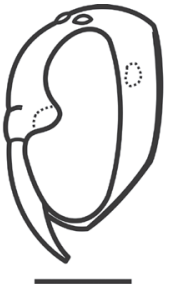

19

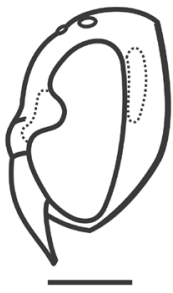

20

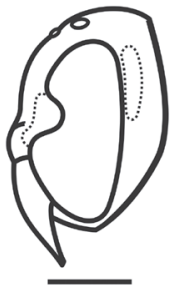

21

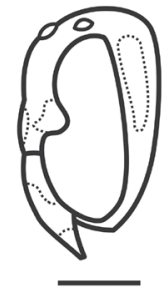

22
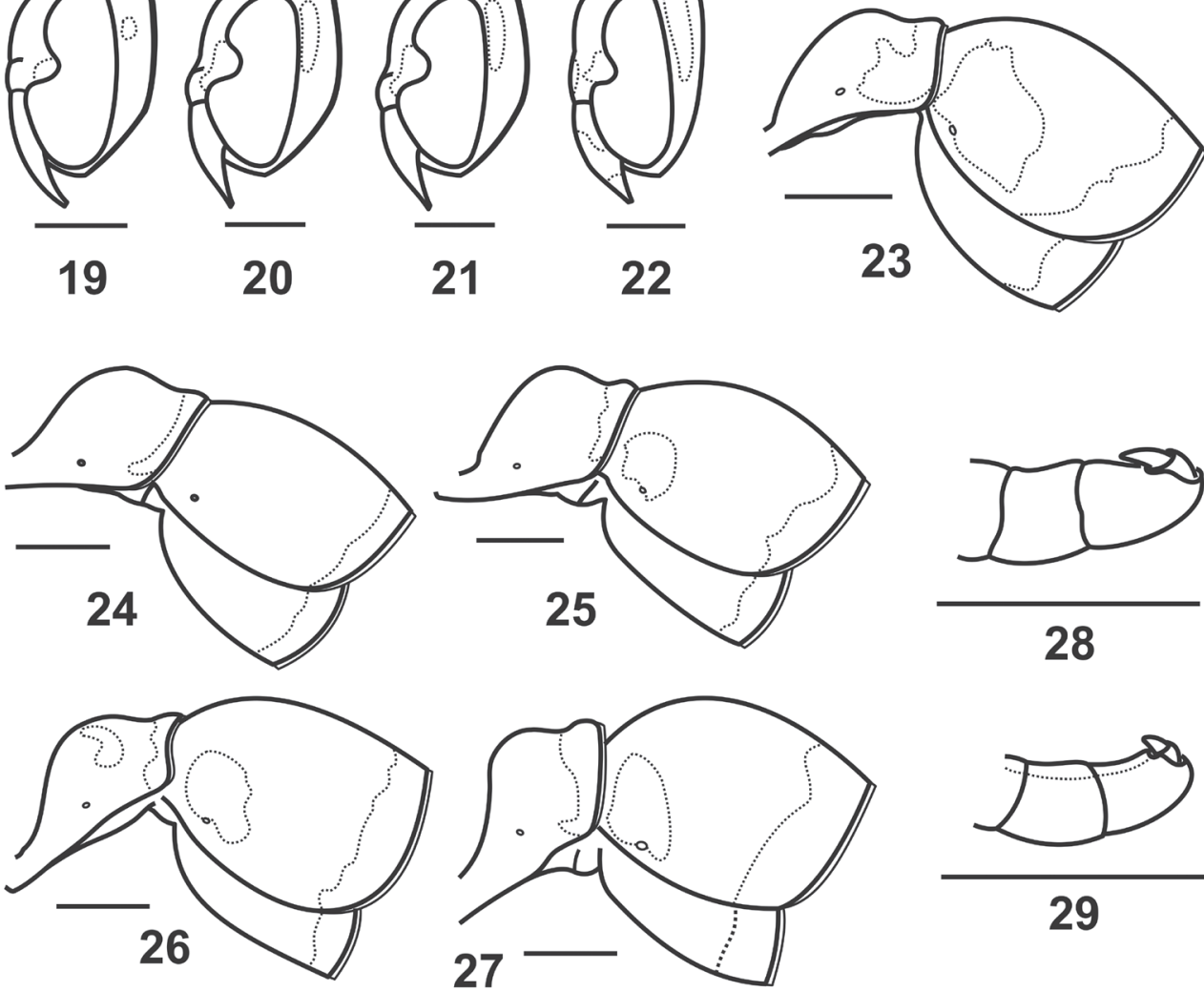

Figures 19-29. Apodynerus species. 19-27 $\odot$ 28-29 $\bigcirc$ 19, 24, 29 A. icarioides 20, 23 A. flavospinosus, holotype 25 A. troglodytes 2I, 26 A. yayeyamensis 22, 27, 28 A. quadricolor 19-22 Head, lateral view 23-27 Metasomal segments I-II, lateral view 28, 29 Apical part of antenna. Scale $1 \mathrm{~mm}$.

teeth, paired large dorsal spots on propodeum; markings on metasoma as in female, but terga IV-V with posteromedian yellow spot.

Color variation in males from Taiwan. Sublateral yellow bands on tergum I in some specimens reduced to small spots or lacking, terga IV-V and occasionally also VI with posteromedian yellow spot, and sternum III sometimes with apical yellow band.

Material examined. JAPAN: $1 \hat{\sigma}$ (SEIHU; lectotype of Apodynerus yayeyamensis), labeled "SK, Japan Matsumra, Yaeyama, VIII 07”, “Odynerus n. sp. yayeyamensis, det. Matsumura", "Type Matsumura", and "Pachymenes fragilis (Smith) det. K. Yasumatsu, 1938”; 1 +, Motobu, Sesoko I., 9 Sep.1982, J. Kojima (IUNH). TAIWAN: 2 ô, Tojuko, Prov. Taichu [=Taichung], 1-8 Aug.1931, N. Owaki (SEIHU).

Remarks. Matsumura and Uchida (1926) mentioned the two males collected on "Okinawa-honto" [=Okinawa Island] by S. Kiyamu and S. Sakaguchi in the description of Odynerus yayeyamensis [= Apodynerus yayeyamensis]. Although, as Yamane (1990) pointed out, the locality "Yaeyama" written on the label was not mentioned in 
the original description, the two male specimens referred to by Yamane (1990:137) as "The type specimen" and that "believed to be the one in the type-series" are certainly the syntypes. Yamane (1990: 137) inadvertently designated the lectotype by specifically referring to one of the two syntypes as "The type specimen" (Article 74.6.1 in the Code, ICZN 1999). The lectotype we located in the SEIHU bears the following labels: (1) on upper side "SK" [=?S. Kiyamu] in handwriting and "Japan Matsumra" in print; on underside, "Yaeyama" [Chinese characters] and "VIII 07" [=August 1907; Yamane (1990) read "vii[?] 0'7”], both in handwriting, (2) "Odynerus n.sp. yayeyamensis" in handwriting, and "det. Matsumura" in print, (3) red label "Type Matsumura" in print, (4) Pachymenes fragilis (Smith) det. K. Yasumatsu, 1938” in handwriting. We have added a label "LECTOTYPE [in red]/Odynerus yayeyamensis/Matsumura, 1926/by designation of/Yamane (1990)" [a slash denotes the start of a new line]. We searched in vain in the SEIHU for the other specimen, the paralectotype, that according to Yamane (1990) is labeled (1) "56" in handwriting and (2) "Okinawa S. Sakaguchi” in print.

\section{Apodynerus quadricolor Giordani Soika, stat. n.}

Figs 12, 16, 22, 27, 28

Apodynerus yayeyamensis tricolor Giordani Soika 1994: 209 (key), [incorrect spelling]. Apodynerus yayeyamensis quadricolor Giordani Soika 1994: 215, §̋우 "C. Sumba: Lokojengo", holotype $\widehat{\jmath}$ (RMNH).

Diagnosis. Apodynerus quadricolor is distinguished from A. yayeyamensis in the following characters [states for the latter are given in the brackets]: clypeus in frontal view proportionally narrower, about $1.1 \times$ as wide $[1.2 \times$ as wide] as high in female (Fig. 12) and slightly narrower [wider] than high in male (Fig.16); gena narrow (Fig. 22) [wider (Fig. 21)]; vertical anterior face of pronotum with series of striae faintly produced [distinct and conspicuously produced]; mesosoma more or less stout [slenderer], in lateral view about $1.2[1.4] \times$ as long as high, in dorsal view about $1.2[1.4] \times$ as long as wide; metanotum with posterodorsal margin rather sharply dentiform [obtusely dentiform]; metasomal tergum I in lateral view with dorsal margin arising after short distance from [at] basal slit; metasomal tergum II with dorsal margin basally strongly convex (Fig. 27) [less convex (Fig. 26)].

Description. Color. MALE. Black, with following bright-colored markings: yellowish-orange: band on gena, interantennal spot, ocular sinus, anterior half of dorsal face of pronotum, large scrobal spot on mesepisternum, tegula except semitransparent ferruginous median spot, parategula, scutellum nearly entirely, paired small lateral spots on metanotum, dorsal face of propodeum, paired large anterolateral spots on metasomal tergum II; yellow: clypeus except dark-brown median spot and ferruginous semitransparent ventral part, mandible basally, posteromedian spot on metasomal terga V and VI; apical bands on metasomal tergum I and segment II pale yellow. Antenna pale ferruginous, 
darker dorsally. Pronotal lobe dark ferruginous. Coxae black; trochanters, femora, tibiae, and tarsi ferruginous. Fore wings ferruginous, slightly darker along anterior margin.

Female. Markings as those on male, but clypeus black with yellow dorsal spot and ventral scrobal spot, only metasomal tergum $\mathrm{V}$ apically with median yellow oval spot.

Material examined. INDONESIA: Sumba I.: 1 ô, $9^{\circ} 40^{\prime} \mathrm{S}, 119^{\circ} 51^{\prime} \mathrm{E}$, Sumba Timur, 30 Jan.2003, J. Kojima (IUNH); 2 ô, $10^{\circ} 02.247^{\prime} S, 120^{\circ} 03.332^{\prime} \mathrm{E}$, alt. about 350 m, Laiwangi, 17 Jun.2010, A. Perrard (MZB); 1 \&, 945'S, $120^{\circ} 35^{\prime}$ E, Sumba Timur, 29 Jan.2003, J. Kojima \& R. Ubaidillah (MZB).

Remarks. Giordani Soika (1994) described A. yayeyamensis quadricolor based on two males and one female collected in Central Sumba. Our specimens from Sumba more or less agree with his original description of quadricolor, while as mentioned above they are different from the specimens of A. yayeyamensis (including the lectotype) enough to allow us to conclude that quadricolor is a distinct species.

\section{Apodynerus troglodytes troglodytes (de Saussure)}

http://species-id.net/wiki/Apodynerus_troglodytes_troglodytes

Figs 25, 30-47

Odynerus troglodytes de Saussure, 1856: 249, Ô, "le Sénégal" [type locality doubtful: Yamane (1990) mentioned "Vecht (pers. comm., 1981) ... doubts Saussure's statement about the type locality."], type (MRSN).

Odynerus fragilis Smith, 1857: 61, Ô, "Borneo", type (BMNH).

Odynerus petulans Smith, 1861: 89, +, "Makassar", type (OUM).

Odynerus lybas Cameron, 1902: 114, o,, "Sarawak", type (BMNH).

Odynerus drescheri Cameron, 1905: 77, + , "Tjandi near Semarang”, type (BMNH).

Odynerus brooksii Cameron, 1908: 561, Ô, "Kuching, Sarawak, Borneo", type depository unknown.

Pachymenes fragilis var. karimonensis van der Vecht, 1937: 278, 우스, "Karmon Djawa Islands", holotype + ( MZB). Syn. n.

Pachymenes troglodytes baliensis Giordani Soika, 1987: 145, 우 đ, "Bali: Samur”, holotype + (MVEN). Syn. n.

Diagnosis. Apodynerus troglodytes is similar to A. yayeyamensis, but can be distinguished from the latter by the following characters: Ventral margin of clypeus proportionally wide (Figs 41-47), about $0.3 \times$ the maximum width of clypeus; female clypeus slightly wider than high, $1.1 \times$ as wide as high (Fig. 41); male clypeus proportionally narrower than that of female, about as wide as high (Fig. 45); metasomal tergum I in lateral view with dorsal margin arising in slightly convex line from the basal slit, then broadly curved down to slight preapical convexity (Fig. 25); tergum II in lateral view more or less evenly and weakly convex dorsally.

Material examined. HONG KONG: 1 , Pak Sha O, 70 m, 24 Apr.-14 May.2009, C. Barthelemy (IUNH). VIETNAM: 1 ô, TT Mai, Chau, Hoa Binh, 3 Jun.2012, P.H. 


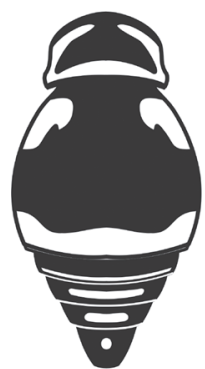

30

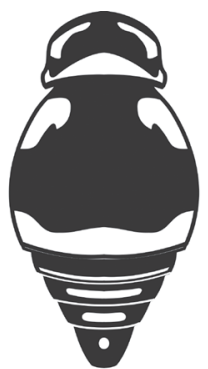

31

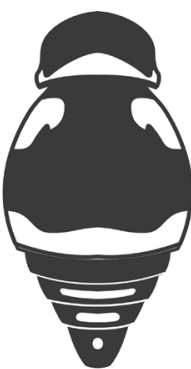

32

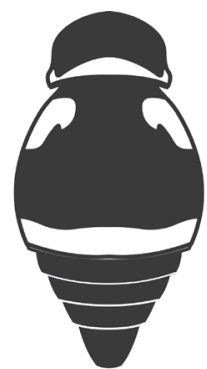

33

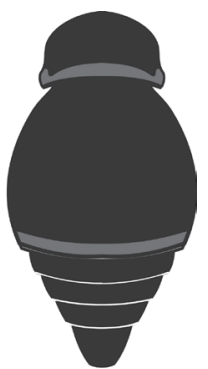

34

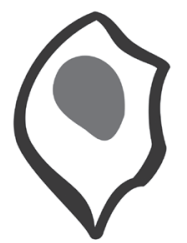

35

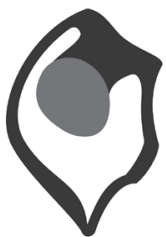

36

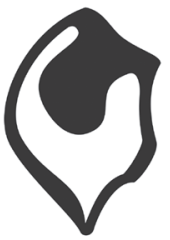

37

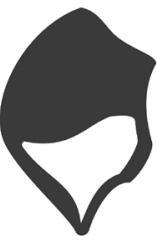

38

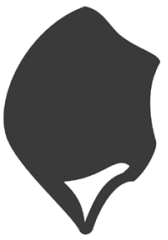

39

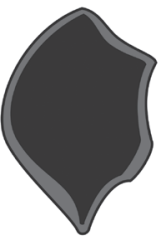

40

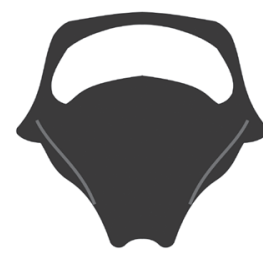

41

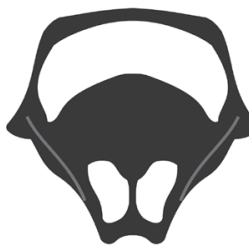

42

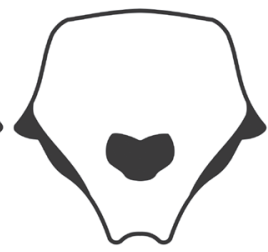

43

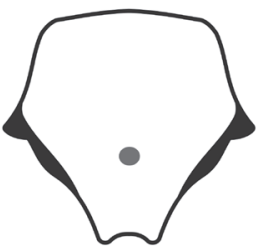

44

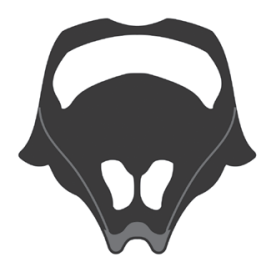

45

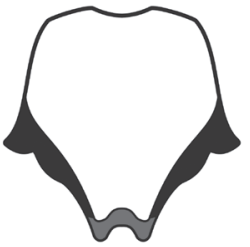

46

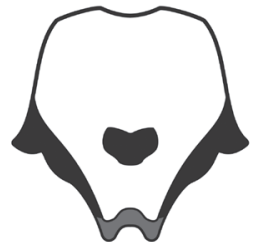

47

Figures 30-47. Marking patterns of Apodynerus troglodytes. For the variations in Indian specimens, after Kumar et al. (2013). 30 Java, Kangean Is., Bali 3 I Kangean Is., Java, Bali, Kepulauan Seribu, Krakatau, Lesser Sunda, Moluccas 32 India, Hongkong, Vietnam, Malay peninsular, Sumatra, Java, Bali, Krakatau, Kangean Is., Borneo, Lesser Sunda 33 Sumatra, Krakatau, Java, Borneo, Lesser Sunda, Sulawesi, Moluccas 34 Karimunjawa Is. 35 Kangean Is., Krakatau, Bali 36 India, Sumatra, Krakatau, Java, Bali, Kangean Is., Borneo, Sulawesi 37 India, Hongkong, Sulawesi, Java, Bali 38 India, Vietnam, Malay peninsular, Sumatra, Krakatau, Java, Borneo, Lesser Sunda, Sulawesi 39 Sumatra, Krakatau, Lesser Sunda, Borneo, Moluccas 40 Karimunjawa Is., Sulawesi 4 I Karimunjawa Is. 42 India, Hongkong, Sumatra, Java, Krakatau, Borneo, Lesser Sunda, Sulawesi 43 Sumatra, Kepulauan Seribu, Krakatau, Java, Kangean Is., Bali, Sulawesi, Lesser Sunda, Moluccas 44 Kangean, Bali 45 India, Sumatra, Karimunjawa Is., Borneo, Sulawesi 46 Krakatau, Kangean Is., Java, Bali, Lesser Sunda 47 Vietnam, Malay peninsular, Sumatra, Krakatau, Java, Kangean Is., Borneo, Sulawesi, Lesser Sunda, Moluccas 30-34 metasoma 35-40 tegula 4I-44 female clypeus 45-47 male clypeus. 
Phong (IUNH). MALAYSIA: Peninsular Malaysia: 1 đ̃, Bukit Fraiser, 20 Jan.1991, T. Matsumura (IUNH); 1 d, Kuala Tahan, 31 Aug.1970, R. Jander (SEIHU). INDONESIA: Sumatra I.: 1 q, 4 ô, Sekincau, S. Sumatra [= Lampung], 23 Jul.1982, Sk. Yamane (MZB); 1 đ̃, Labuan Batu, Kec. Jabung, Lampung Tengah, 5 Nov.1975, S. Ach$\operatorname{mad}(\mathrm{MZB}) ; 1$ ô, West Sumatra, Kec. Limau Manis, Andalas University, 054.683'S, $100^{\circ} 28.35^{\prime} E$, 23. Sep.2010, H. Nugroho \& J. Kojima (MZB); Sunda Strait I.: 2 , P. Sebuku, S. Sumatra, 15 Jun.1955, AMR Wegner (MZB); 1 †, 1 ふ̋, P. Legundi, S. Sumatra, + 19, Jun, đ̂ 21 Jun.1955, AMR Wegner (MZB); 4 गे, P. Rakata Kecil, Krakatau, 27 Jul.1982, Sk. Yamane (MZB); 1 đ̊, P. Anak Krakatau, 10 Jul.1982, Sk. Yamane

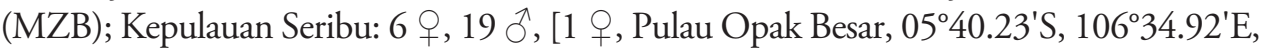
9 Mar.2005; 1 ๆ, 1 ơ, Pulau Kotok Besar, 0541.976'S, 106³2.254'E, 10 Mar.2005;

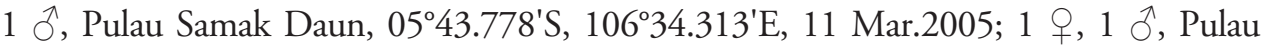

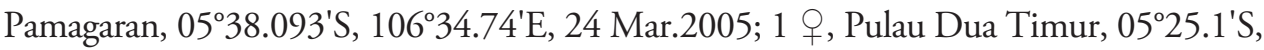
106²9.4'E, 9 Apr.2005; 2 đ̃, Pulau Bira Kecil, 05³7.6'S, 106³4.53'E, 12 Apr.2005; 1

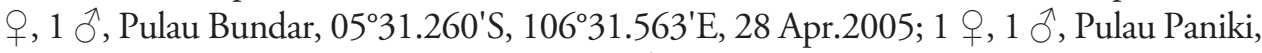
0541.726'S, 106 42.675'E, 30 Apr.2005; 4 ô', Pulau Bokor, 0556.744'S, 106 37.917'E, 5 May.2005; 2 đ̃, Pulau Lancang Besar, 0555.867'S, 106³5.230'E, 7 May.2005; 3 ō, Pulau Rambut, 0558.680'S, 10641.569'E, 9 May.2005; 3 ỏ, Pulau Untung Jawa, 0558.611'S, $106^{\circ} 42.181^{\prime} E, 11$ May.2005], A. Spengler (MZB); Java I.: 1 \%, 2 ò, Car-

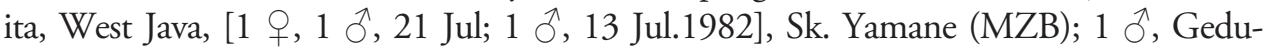
wang, Baturetno, Wonogiri, Central Java, 24 Jul.2008, H. Nugroho \& Giyanto (MZB); 1 ơ, 741.73'S, $110^{\circ} 28.99^{\prime} \mathrm{E}$, alt. about $280 \mathrm{~m}$, Manisrenggo, Klaten, Central Java, 30 Jun.2009, H. Nugroho (MZB); Kangean Is.: 4 q, 5 đ̃, Bujutan, [3q, 23 Aug; 1 q, 21 Aug; 5 ふૈ, 23 Aug. 1954], A. Hoogerwerf (MZB); Karimunjawa Is.: 1 † (MZB; holotype of Pachymenes fragilis var. karimonensis), 1 ते (MZB; paratype - allotype of Pachymenes fragilis var. karimonensis), "Karimon Djawa", 22-20 Nov.1930, M.A. Lieftinck; Kalimantan I.: 1 q, 1 $\hat{\jmath}$, Central Kalimantan, Hutan Gambut Kalampangan, Palangkaraya, Pemantang Kanal, 02 ${ }^{\circ} 17.956$ 'S, $114^{\circ} 01.625^{\prime} \mathrm{E}$, alt. about 15 m, 31. May.2003, S Kahono (MZB); 2 , 1 đ̃, E. Borneo, Samarinda, Muara Kaman, alt. about 50 m, Nov.1950, AMR Wegner (MZB); 3 q, 4 गे, E. Borneo, Balikpapan [2 o, Wain River, alt. about 50 m, Nov.1950; 1 ㅇ, 4 गे, Mentawir River, alt. about 50 m, Oct.1950], AMR Wegner (MZB); Bali I.: 1 ๆ , $8^{\circ} 08^{\prime}$ S, $115^{\circ} 04^{\prime} E$, Singaraja, 9 Sep.2005, J. Kojima \& R. Ubaidillah (IUNH); 1 đ̃, Tanah Lot, 10 Sep.2005, J. Kojima \& R. Ubaidillah (IUNH); Lombok I.:

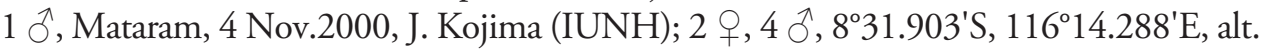
about 270 m, Aiq Nyet, Lingsar, Lombok Barat, 28 Mar.2010, H. Nugroho (MZB); 1 + , $8^{\circ} 34.010^{\prime} \mathrm{S}, 116^{\circ} 14.009^{\prime} \mathrm{E}$, alt. about $255 \mathrm{~m}$, TWA Suranadi, Narmada, 27 Mar.2010, H. Nugroho (MZB); 1 †, $8^{\circ} 33.065^{\prime} \mathrm{S}, 116^{\circ} 25.245^{\prime}$ E, alt. about $590 \mathrm{~m}$, Tetebatu, Sikur, Lombok Timur, 3 Apr.2010, H. Nugroho (MZB); Sumbawa I.: 1 đૈ, Batudulang, Batulanteh, Sumbawa Besar, 10 Nov.2000, J. Kojima (IUNH); 1 q, 1 đ̊, 8³7.555'S, $117^{\circ} 10.71^{\prime} \mathrm{E}$, alt. about 920 m, Tepal, Batu Lanteh, [, 14 Apr.; §’, 16 Apr.2010], H. Nugroho \& Y.R. Suhardjono (MZB); Sulawesi I.: 2 q, [Remboken, Tondano; Rurukan, Tomohon], Minahasa Peninsula, 27 Nov.1999, J. Kojima (IUNH); 1 q, 2 §̊, Tompasu, Remboken, Minahasa peninsula, 29 Nov.1999, J. Kojima (IUNH). 
Remarks. This species, widely distributed in southern Asia from India in the west to Moluccas and Lesser Sunda Islands (Lombok and Sumbawa, new records) in the east, is represented by four color forms formally recognized as subspecies, of which two are so far known respectively only from Bali (baliensis) and Karimunjawa Islands (karimonensis). As mentioned below, after examination of specimens from various localities mainly in the Indonesian Archipelago, we have reached the conclusion that $A$. t. baliensis and $A$. t. karimonensis are synonyms of $A$. troglodytes. We tentatively treat shanensis Giordani Soika, 1994 as a subspecies of $A$. troglodytes (see the checklist) until we have a chance to examine specimens of $A$. troglodytes from Myanmar including the type of A. t. shanensis.

Giordani Soika (1987) described Pachymenes troglodytes baliensis based on the female holotype and two males (paratypes) from Bali, and according to him this subspecies is characterized by more extensive yellow markings than typical troglodytes as follows: tegula and parategula entirely, paired sublateral bands and apical band on metasomal tergum I (Figs 30, 31), paired basal spots and apical bands both on tergum and sternum II, traces of apical band on tergum III, narrow apical band on sternum III, and narrow posteriomedian bands on terga IV-V. Our examination of the large number of specimens listed above, mainly from Java and Kangean Islands, shows that extensive variation in markings even occurs within local populations, thus baliensis would not be treated as a subspecies even if the subspecies had a position in the phylogenetic system. Van der Vecht (1937) treated the Karimunjawa Islands population of $P$. troglodytes as a distinct color variety and named it Pachymenes fragilis var. karimonensis. This local population is characterized by markings much reduced (Figs 34, $40,41,45)$. The Karimunjawa Islands population does not have any morphological characters justifying treating it as a valid species, and thus $A$. t. karimonensis (van der Vecht, 1937) is synonymized under $A$. troglodytes (de Saussure, 1856).

\section{Revised species checklist of the genus Apodynerus}

Kumar et al. (2013) provided a checklist of the world species of Apodynerus, which included 15 species-group taxa (nine species and six subspecies). Below a revised species checklist is provided with detailed nomenclatural information.

Apodynerus sparsipunctatus Gusenleitner, 2008 described from New Caledonia was synonymized under Parodynerus quodi (Vachal, 1907) by Gusenleitner and Madl (2011) and is not included here.

\section{Apodynerus amandus Gusenleitner, 2002}

Apodynerus amandus Gusenleitner, 2002: 1091, 1093, ô, શ, “Thailand, Chiang Mai: Maerim", holotype $\overparen{ }$ (LACM).

Distribution. Thailand: North Thailand. 
Apodynerus diffinis Giordani Soika, 1996

Apodynerus diffinis Giordani Soika, 1996: 36, §̂, "Sulawesi: Patunuang", holotype (MVEN).

Distribution. Indonesia: Sulawesi.

Apodynerus flavospinosus (Giordani Soika, 1986)

Pachymenes flavospinosus Giordani Soika, 1986: 80, ㅇ, đે, "Naga Naga, Leyte, Palo", holotype + (IUNH).

Apodynerus flavospinosus; Giordani Soika 1994: 207 (key), 216.

Distribution. Philippines: Luzon, Leyte, Mindanao, Palawan.

Apodynerus formosensis formosensis (von Schulthess, 1934)

Odynerus formosensis von Schulthess, 1934: 101, Ô, શ, "Formosa" [=Taiwan], syntypes (ETHZ).

Apodynerus formosensis formosensis; Giordani Soika 1994: 208 (key), 217.

Distribution. Taiwan.

Apodynerus formosensis continentalis Giordani Soika, 1994

Apodynerus formosensis continentalis Giordani Soika, 1994: 208 (key), 217, + , ô, "Cina: Kukien, Kuatun", holotype $q$ (MVEN).

Distribution. China; Laos; Vietnam.

\section{Apodynerus formosensis indicus Giordani Soika, 1994}

Apodynerus formosensis indicus Giordani Soika, 1994: 208 (key), 218, + , "Nepal: Taplejung Distr., Snagu, $6500 \mathrm{ft}$ ", holotype (BMNH).

Distribution. Nepal. 
Apodynerus gregarioides (Giordani Soika, 1986)

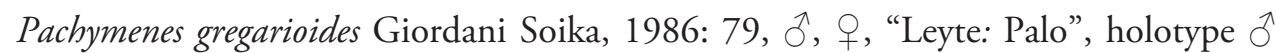
(IUNH).

Apodynerus gregarioides; Giordani Soika 1994: 208 (key), 219.

Philippodynerus omicroniformis Gusenleitner, 1996: 39, 40, đ, "Philippines, Palo, Leyte, Naga-Naga", holotype (SEIHU). Syn. n.

Distribution. Philippines: Luzon, Leyte; ?Indonesia: Sumba.

\section{Apodynerus icarioides (Bingham, 1897)}

Odynerus icarioides Bingham, 1897: 363 (key), 372, , “Tenasserim”, type (BMNH). Pachymenes icarioides; van der Vecht 1937: 278.

Apodynerus icarioides; Giordani Soika 1994: 208 (key), 219.

Distribution. India: Assam, Sikkim; Myanmar; Malaysia: Sarawak, Sabah; Indonesia: Kalimantan.

Apodynerus nitidiclypeus Gusenleitner, 2013

Apodynerus nitidiclypeus Gusenleitner, 2013: 121, 125, figs 11-15, +, Ō, "Vietnam, Dak Lak Prov., Easo, $12^{\circ} 55^{\prime} \mathrm{N} 108^{\circ} 38^{\prime} \mathrm{E}$, holotype $q$ (OLM).

Distribution. Vietnam.

Apodynerus quadricolor Giordani Soika, 1994

Apodynerus yayeyamensis tricolor Giordani Soika 1994: 209 (key), [incorrect spelling]. Apodynerus yayeyamensis quadricolor Giordani Soika 1994: 215, ô, ㅇ, "C. Sumba: Lokojengo", holotype $\hat{\jmath}$ (RMNH).

Distribution. Indonesia: Sumba.

\section{Apodynerus rufipes Giordani Soika, 1994}

Apodynerus rufipes Giordani Soika, 1994: 207 (key), 214, q, “Flores: Ruteng”, holotype (RMNH).

Distribution. Indonesia: Flores. 


\section{Apodynerus troglodytes troglodytes (de Saussure, 1856)}

Odynerus troglodytes de Saussure, 1856: 249, đ̂, "le Sénégal " [type locality doubtful], type (MRSN).

Odynerus fragilis Smith, 1857: 61, Ô, "Borneo", type (BMNH). Synonymized by Yamane (1990).

Odynerus petulans Smith, 1861: 89, + , "Makassar", type (OUM). Synonymized by van der Vecht (1937).

Odynerus lybas Cameron, 1902: 114, , "Sarawak", type (BMNH). Synonymized by van der Vecht (1937).

Odynerus drescheri Cameron, 1905: 77, $q$, “Tjandi near Semarang”, type (BMNH). Synonymized by van der Vecht (1937).

Odynerus brooksii Cameron, 1908: 561, Õ, "Kuching, Sarawak, Borneo", type depository unknown. Synonymized by van der Vecht (1937).

Pachymenes fragilis; van der Vecht, 1937: 277.

Pachymenes fragilis var. karimonensis van der Vecht, 1937: 278, q ô, "Karmon Djawa Islands", holotype + (MZB). Syn. n.

Antepipona fragilis; Lee 1982: 218, 220.

Pachymenes troglodytes baliensis Giordani Soika, 1987: 145, ㅇํ, "Bali: Samur”, holotype $Q$ (MVEN). Syn. $\mathbf{n}$.

Apodynerus troglodytes troglodytes; Gusenleitner 1988: 180.

Apodynerus "(VAN DER VECHT i. 1.)" troglodytes; Gusenleitner 1991: 258.

Pachymenes troglodytes; Giordani Soika 1991: 164.

Apodynerus troglodytes; Giordani Soika 1993a: 156, fig.

Apodynerus troglodytes baliensis; Giordani Soika 1994: 209 (key), 212.

Apodynerus troglodytes karimonensis; Giordani Soika 1994: 209 (key), 213.

Distribution. India; Andaman and Nicobar Islands; China; Hong Kong; Myanmar; Thailand; Laos; Malaysia: Peninsular Malaysia, Sarawak, Sabah; Singapore; Indonesia: Sumatra, Krakatau Islands, Kepulauan Seribu (new record), Java, Kangean Islands, Bali, Karimunjawa Islands, Sulawesi, Moluccas, Lombok (new record), Sumbawa (new record).

\section{Apodynerus troglodytes shanensis Giordani Soika, 1994}

Apodynerus troglodytes shanensis Giordani Soika 1994: 209 (key), 213, §̂, ᄋ, "Burma: Shan State, estremità $S$ del lago Inle, Taugdo, 900 m”, holotype ô (RMNH).

Distribution. Myanmar. 


\section{Apodynerus yayeyamensis (Matsumura, 1926)}

Odynerus yayeyamensis Matsumura 1926, in Matsumura and Uchida, 1926: 36, Ô, "Okinawa (Okinawa-honto)" [possibly erroneously listed locality], lectotype from Yaeyama Islands (SEIHU).

Odynerus hokotoensis Sonan 1929: 534, q $\widehat{A}$, [Taiwan:] "Hôkotô ... Takao". Holotype ㅇ originally in "Entomological Laboratory, Taihoku Imperial University", but current depository unknown. Synonymized by Yamane (1990).

Pachymenes yayeyamensis; Giordani Soika, 1986: 65, figs 5-9.

Apodynerus yayeyamensis yayeyamensis; Giordani Soika 1994: 209 (key), 215.

Distribution. Taiwan; Japan: Ryukyu Islands

\section{Acknowledgments}

The present study was supported by the RONPAKU program of the Japan Society for the Promotion of Science. We thank M. Ohara for arranging loans of the specimens in the Systematic Entomology Institute, Hokkaido University Museum and J. M. Carpenter for his valuable comments on an earlier draft of the manuscript.

\section{References}

Bingham CT (1897) The Fauna of British India, including Ceylon and Burma: Hymenoptera Vol. 1, Wasps and Bees. Taylor and Francis, London, 1-579.

Cameron P (1902) On the Hymenoptera collected by Mr. Robert Shelford in Sarawak, and on the Hymenoptera of the Sarawak Museum. Journal of the Straits Branch of the Royal Asiatic Society 37: 29-131.

Cameron P (1905) On the Malay fossorial Hymenoptera and Vespidae of the museum of the R. Zool. Soc. "Natura Artis Magistra" at Amsterdam. Tijdschrift voor Entomologie 48: 48-78.

Cameron P (1908) On some undescribed Vespidae from Borneo (Hym.). Deutsche Entomologische Zeitschrift 1908: 561-565.

Carpenter JM, Cumming JM (1985) A character analysis of the North American potter wasps (Hymenoptera: Vespidae; Eumeninae). Journal of Natural History 19: 877-916. doi: 10.1080/00222938500770551

Giordani Soika A (1986) Eumenidi di Okinawa e delle Filippine Raccolti da J. Kojima. Bollettino del Museo civico di storia naturale di Venezia 35: 67-89.

Giordani Soika A (1987) Eumenidi raccolti a Bali e Borneo da T. Hedwiust (Hymenoptera). Bollettino del Museo Civico di Storia Naturale di Venezia 37: 145-150.

Giordani Soika A (1991) Eumenidi Raccolti in Indonesia da G. Osella EJ. Klapperich. Bollettino del Museo Civico di Storia Naturale di Verona 15: 163-166. 
Giordani Soika A (1993a) Di alcuni nuovi Eumenidi della Regione Orientale (Hym. Vespoidea). Bollettino del Museo civico di storia naturale di Venezia 42: 151-163.

Giordani Soika A (1993b) Noona Dan Expedition 1961-62: Hymenoptera, Eumenidae. Lavori Società veneziana di Scienze naturali 18: 19-24.

Giordani Soika A (1993c) Eumenidi di Sulawesi e Borneo raccolti da C. van Achterberg (Hymenoptera, Eumenidae). Lavori Società veneziana di Scienze naturali 18: 25-31.

Giordani Soika A (1994) Ricerche sistematiche su alcuni generi di Eumenidi della Regione Orientale e della Papuasia (Hymenoptera, Vespoidea). Annali del Museo Civico di Storia Naturale "G. Doria" 90: 1-348.

Giordani Soika A (1996) Eumenidi orientali e Papuani nuovi o poco noti. Bollettino del Museo civico di storia naturale di Venezia 45: 35-45.

Gusenleitner J (1988) Über Eumenidae aus Thailand, mit einer Bestimmungstabelle für Orientalische Labus-Arten (Hymenoptera, Vespoidea). Linzer Biologische Beitrage 20 (1): 173-198.

Gusenleitner J (1991) Über Eumeniden der Insel Sulawese (Indonesien) (Vespoidea, Hymenoptera). Linzer Biologische Beitrage 23(1): 257-265.

Gusenleitner J (1996) Über Eumenidae der orientalischen Region (Hymenoptera, Vespoidea). Linzer Biologische Beitrage 28(1): 39-56.

Gusenleitner J (2002) Bemerkenswerte Faltenwespen-Funde aus der orientalischen Region Teil 2 (Hymenoptera: Vespoidea, Eumenidae). Linzer Biologische Beitrage 34(2): 1091-1099.

Gusenleitner J (2008) Bemerkenswerte Faltenwespen-Funde aus der orientalischen Region Teil 4. Mit einem Anhang über eine Art aus Neu-Kaledonien (Hymenoptera: Vespidae, Eumeninae). Linzer Biologische Beitrage 40(2): 1495-1503.

Gusenleitner J (2013) Bemerkenswerte Faltenwespen-Funde aus der orientalischen Region Teil 7 (Hymenoptera: Vespidae, Eumeninae, Polistinae). Linzer Biologische Beitrage 45 (1): 121-132.

Gusenleitner J, Madl M (2011) Annotated catalogue of the Vespidae (Hymenoptera: Vespoidea) of New Caledonia. Zeitschrift der Arbeitsgemeinschaft Österreichischer Entomologen 63: $133-140$.

Kumar PG, Shareef KPM, Kishore L, Carpenter JM (2013) A taxonomic study on the oriental genus Apodynerus Giordani Soika (Hymenoptera: Vespidae: Eumeninae) from the Indian subcontinent. Biosystematica 7(1): 23-31.

Matsumura S, Uchida T (1926) Die Hymenopteren-Fauna von den Riukiu-Inseln. Insecta Matsumurana 1(1): 32-52.

Saussure H de (1852) Études sur la Famille des Vespides 1. Monographie des Guêpes solitaires ou de la tribu des Euméniens. V. Masson (Paris) and J. Kessmann (Genève): i-1 + 1-286.

Saussure H de (1856) Études sur la Famille des Vespides 3. La Monographie des Masariens et un supplément à la Monographie des Euméniens. V. Masson (Paris) and J. Kessmann (Genève): 1-352.

Schulthess A von (1934) Zur Kenntnis der Odynerusarten (Vespidae, Hym.) der japanischen Subregion (China, Japan, Formosa, Philippinen) mit besonderer Berücksichtigung der Sammlungen des Deutschen Entomologischen Instituts, Berlin-Dahlem. Arbeiten über Morphologische und Taxonomische Entomologie 1: 91-101. 
Smith F (1857) Catalogue of Hymenopterous Insects in the Collection of the British Museum, Part V, Vespidae. London, 147 pp.

Smith F [1860 (1861)] Descriptions of new species of Hymenopterous insects collected by Mr. A. R. Wallace at Celebes. Journal of the Proceedings of the Linnean Society of London, Zoology 5: 57-93.

Sonan J (1929) Some wasps and bees of Hôkotô (Pescadores Islands). Transactions of the Natural History Society of Formosa 19: 533-540.

Vecht J van der (1937) Descriptions and records of Oriental and Papuan solitary Vespidae (Hym.). Treubia 16: 261-293.

Yamane S (1990) A revision of the Japanese Eumenidae (Hymenoptera, Vespoidea). Insecta matsumurana, new series 43: 1-189. 